\title{
Urban food markets and the COVID-19 lockdown in India ${ }^{1}$
}

\author{
Sudha Narayanan ${ }^{2}$
}

Shree Saha $^{3}$

\footnotetext{
${ }^{1}$ This article is part of a larger research effort to understand the consequences of the lockdown in response to Covid 19 on agri-food markets and supply chains. We thank volunteers from Hard Work, No Pay for participating in the Food Price Survey. We also thank Karthikeya Naraparaju for his assistance, Meraj Ahmed, Nishant Gupta and Aaditeshwar Seth for support with data. We remain responsible for the contents of this paper.

${ }^{2}$ Sudha Narayanan is Associate Professor, Indira Gandhi Institute of Development Research (IGIDR), Mumbai. Email: sudha@igidr.ac.in.

${ }^{3}$ Shree Saha is a Graduate Student, Dyson School of Applied Economics and Management, Cornell University, Ithaca.Email:ss3898@cornell.edu.
} 


\title{
Urban food markets and the COVID-19 lockdown in India
}

\author{
Sudha Narayanan
}

Shree Saha

\section{Introduction}

The first COVID-19 case in India was confirmed on January 30, 2020. By March 22, 2020, as the number of positive cases grew, several state governments had issued orders to contain the spread of the disease, shutting down schools, malls and restaurants and urging people not to congregate for social, religious or sporting events. On March 22, 2020, the Prime Minister called for a People's Curfew ("Janata Curfew") urging people to stay home for a day. This served as a prelude to the key action of the Government of India to slow down the spread of COVID-19 that came on March 24, 2020, when the Prime Minister announced a nationwide lockdown for 21 days, until April 14, 2020 and eventually to May 3, 2020 and then yet again to May 31, 2020. India's lockdown was unusual, compared with those in other countries, because it was announced with only four hours' notice, giving people little time to prepare for what would come to be known as among the most stringent implemented worldwide, according to the "Oxford COVID-19 Government Response Tracker". ${ }^{4}$

Although, in principle, the lockdown allowed free movement "essential" commodities and was supposed to allow food markets to function without impediments, in reality, those involved in food supply faced insurmountable challenges, including intermittent closure of wholesale markets for agricultural produce (Rawal and Kumar, 2020) and restrictions and disruption on movement of vehicles, both across state borders and within cities. ${ }^{5}$ It is estimated that more than a hundred thousand trucks were stuck on highways (Ramakumar, 2020). Fishermen who were out at sea on the night of the announcement returned the next morning with their catch, unaware of the lockdown announcement, to find no buyers. ${ }^{6}$ The police appeared to enforce the lockdown with an iron hand, forcing many street vendors of fresh produce to suspend their business and others to restrict hours of operation. ${ }^{7} \mathrm{E}-$ commerce and micro-delivery operations of food and groceries ground to a halt. ${ }^{8}$ Reports of harassment

\footnotetext{
4 The stringency index is based on publicly available information on 13 indicators representing government response and includes those such as school closures, travel bans, internal movement restrictions, etc., fiscal or monetary measures and measures tackling the disease itself. (Hale, et al 2020)

${ }^{5}$ As per the Annexure to the Ministry of Home Affairs Order 40-3/2020 dated 24 March 2020, while commercial establishment of food were exempt from the lockdown, manufacturing and transport was permitted only for essential commodities, implicitly including food.

6 See here, for example, https://www.channelnewsasia.com/news/asia/indian-fishermen-caught-out-bycoronavirus-lockdown-dock-after-12653532

${ }^{7}$ In fact, several reports emerged of policemen harassing and roughing up people who stepped out to buy their groceries. At least two cases of Public Interest Litigation (PIL) were filed in the Supreme Court of India seeking action against police for enforcing the lockdown mercilessly disregarding the guidelines that permitted consumers to venture out for shopping for essentials.

${ }^{8}$ For reports on food delivery see https://timesofindia.indiatimes.com/business/india-business/hostile-cops-hitfood-pharma-delivery-biz/articleshow/74837818.cms and for non-essentials, see https://www.outlookindia.com/website/story/amazon-flipkart-paytm-mall-stops-taking-orders-for-non-essentialitems/349484.
} 
of delivery agents by the police surfaced in many places. ${ }^{9}$ Transporters were reluctant to risk plying their vehicles for fear of being stopped. ${ }^{10}$ In the cities, many of these food retailing activities depended on migrant workers, who had left the city post-lockdown, compounding the operational challenges for many in the food retail sector. Several workers and traders chose to stay home fearing exposure to Covid-19. Wet markets for fish and meats as well as weekly farmers' markets ceased to operate in many cities across the country.

In the immediate aftermath of the lockdown, consumers in the city were panic-buying. As for a substantial proportion of workers in the city who depended on daily wages, loss of work meant that they began relying almost entirely on meals and rations provided by civil society and voluntary organizations or the government. That hunger posed as great a risk to life as the virus became a refrain of many migrant workers (SWAN, 2020; Seth \& Vishwanathan, 2020).

Apart from supply side disruptions, there was a collapse in demand as well. With thousands of eateries, restaurants, institutions shut and an exodus of migrant workers, demand for many commodities such as milk plummeted. Many milk cooperatives took drastic measures and stopped procuring milk from their members to cope with reduced demand. ${ }^{11}$ Early accounts of agri-food supply chains thus convey a sense of chaos, uncertainty and anxiety.

This paper seeks to examine select aspects of the consequences of the lockdown on food markets in India, focusing mainly on wholesale and retail food prices in urban India. We focus on the period, March 24-July 31, 2020. Until May 31, 2020 much of the country was continued to be under a lockdown and thereafter, lockdowns continued in some districts in the country where the COVID19 cases were higher. We bring together evidence from two main sources: First, we analyze daily price data on 22 commodities and 114 cities across India, collected and published daily by the Government of India. ${ }^{12}$ We also draw on three rounds of a survey of retailers, conducted by student volunteers from 21 locations in 14 cities across the country that captures the experiences of urban food retailers and also documenting prices of select commodities. ${ }^{13}$

Our analysis has several limitations. We do not discuss rural food markets, where a majority of Indians live and has likely swelled with migrants who have returned home from the cities consequent to

\footnotetext{
${ }^{9}$ https://www.thequint.com/news/india/police-harassing-citizens-delivery-agents-amid-covid-19-lockdown https://newsable.asianetnews.com/coronavirus-india/coronavirus-lockdown-e-commerce-agents-complain-ofpolice-harassment-during-delivery-q7saj1

11 See for example, MILMA in Kerala that stopped milk procurement https:/timesofindia.indiatimes.com/city/kozhikode/state-stuck-with-surplus-milk/articleshow/74929109.cms ${ }^{12}$ We supplement these with other government sources but given the spotty coverage, we prefer to rely on the daily price data mentioned here.

${ }^{13}$ The cities where the survey was conducted includes Bengaluru (2), Chennai (2), Coimbatore, Delhi (4), Porvorim (2), Gurgaon (2), Hazaribagh, Indore, Kozhikode, Kumbakonam, Latur, Malappuram, Mumbai, Noida. The figure in parenthesis indicates the number of distinct locations where the interview was conducted. Owing to some attrition and small sample size this survey serves merely to highlight some of the issues that supply chain participants faced.
} 
the lockdown. We are also constrained by the limited set of locations and commodities for which prices are available.

Overall, we find that post-lockdown, food retail prices faced by consumers that were until then trending downwards saw a sharp if modest increase in prices; after a brief period of improvement, prices have been on rise again. Price rise has been particularly pronounced in smaller cities than in the more populous ones. Pulses, oils and perishables such as tomato and onions, in particular, have seen significant increases. We also see a marked increase in the gap between retail and wholesale prices, consistent with the increased transactions costs of retail traders operating during the lockdown. The spread of prices across locations has also seen a steep rise, likely on account of transport restrictions that are crucial for integrating markets spatially. While this is likely a temporary phenomenon, these findings do not portend well for the food security of the urban poor in the short term, especially in the face of massive unemployment and a steep drop in earnings (Afridi, et al, 2020; NCAER, 2020).

The paper is organized as follows. Following this introduction, in Section 2, we provide an overview of the food environment in urban India. In section 3, we analyze food prices, elaborating on the data and methods, before presenting the results. In Section 4, we draw on our survey and other existing accounts to discuss the operational challenges faced by food retailers and the ways in which they have attempted to cope with constraints. Section 5 concludes the paper with lessons for the future.

\section{Food Environments in urban India}

Urban food markets in India constitute a mosaic of actors and tends to be highly fragmented (Reardon, et al., 2020; Narayanan, 2008). The supermarket revolution, that began in the mid-1990s in southern India, has since spread across the country. However, despite the robust growth in organized retailing especially in smaller cities, it continues to serve a limited constituency. There are no reliable estimates on the composition of the food retailers in India. An industry estimate suggests that as much as $90 \%$ of the food retail market is serviced by small-scale mom-and-pop stores/ corner stores (called kirana) and other informal players such as push-cart, street vendors; about $8 \%$ constitutes modern organized retail including supermarkets of various formats and $2 \%$ online grocery. Other estimates suggest organized retail is 5\% while a recent estimate from industry analysts RedSeer suggests that though the Fast Moving Consumer Goods (FMCG)/grocery retail market in India is about $\$ 450$ billon (based on 2016 figures), online retailing is at a nascent stage, accounting for only $0.1 \%$ of the total share of the retail market. The estimate of small-scale corner stores ranges from 6.65 million to 15 million kirana stores. Notwithstanding the accuracy of these figures, Indian food retail continues to rely on hyperlocal smallscale brick and mortar kirana stores; modern retail penetration is low as is online grocery retail. In comparison with its south-east Asian neighbours, India's food and grocery sector continues to depend highly on small-scale, often unorganized retail sector. 
The informal retail sector is quite diverse. At one end are itinerant, hand or pushcart vendors and street side sellers, especially for fresh fruits and vegetables. They are often the last link in a chain of intermediaries that can comprise as many as five or six intermediaries. Typically, they procure produce in wholesale markets in the city or from large buyers. They rely on little capital and their margins are typically thin. They often build a long-term relationships with buyers and rely on a stable clientele locally. The kirana stores are often run as family enterprises and sell a wide range of products in a small space. It is not uncommon in these stores to see processed foods made by multinational firms in large scale plants jostle for space with artisanal foods and snacks prepared by individuals, women's groups, and small manufacturers. Many also sell unbranded loose grains, oil, etc. In India, several tech-based companies have recently built relationships with kirana stores as suppliers of inventory, so that although kirana stores are not considered modern retail, their back end and operations have become increasingly sophisticated. Street food is ubiquitous as are informally prepared food delivery services, that are rising in importance.

Supermarkets and online grocers, at the other end, especially those operating with their own inventories tend to have sophisticated procurement systems with strong backward linkages (Reardon, et al., 2020). Supermarkets too operate with different formats (Reardon and Minten, 2010; Narayanan, 2007). The presence of these latter in rural areas and smaller cities continues to be somewhat limited. There are also strong regional differences across the country in the composition of food retailer and consumer shopping preferences over different formats.

A lockdown would therefore likely impact the operations of these actors in different ways and their capacity to adapt to these challenges are likely different as would their strategies for conducting business, including decisions around sourcing, procurement and pricing. We discuss these in Section 4 and focus on food prices in the following section.

\section{What happened to urban food prices during the lockdown?}

\subsection{Data and Methods}

We use daily price data for 22 commodities collected from 114 Centres by the respective State Civil Supplies Departments and published by the Ministry of Consumer Affairs, Food and Public Distribution, Government of India. ${ }^{14}$ These prices include both retail and wholesale prices for rice, wheat, wheat flour (atta), edible oils (mustard, groundnut, sesame, coconut, sunflower, Vanaspati, soyabean and palm), pulses (pigeon pea, split gram, green gram, lentil, black gram), milk, potato, onion and tomato, sugar, jaggery, iodized salt, loose tea leaves. ${ }^{15}$

\footnotetext{
${ }^{14}$ For details see https://consumeraffairs.nic.in/price-monitoring-cell/price-monitoring-cell. The data are published in https://fcainfoweb.nic.in/reports/report menu web.aspx.

${ }^{15}$ Prices of horticultural commodities are available with the National Horticulture Board, but we do not use these since the reporting has been spotty during the lockdown period.
} 
We construct a Food Price Index using these data. To do this, we first calculate a weighted average food price for each Centre for each date, drawing on commodity weights used routinely by the Government of India to compute the Consumer Price Index (CPI) to track inflation. The CPI for Food of the Government of India however comprises a larger basket of 78 food commodities. The index we compute includes only a subset of these commodities for which data are publicly available. We therefore use weights for just the subset, ensuring merely that the weights each commodity gets is in the same proportion as used in the construction of the official CPI. Once we have Centre-date specific food price averages, we aggregate this over all the Centres, weighting these by population of these Centres, as per the Census of India, 2011, to obtain a daily Food Price Index for the country as a whole. We construct these for retail and wholesale prices so that we have a Retail Food Price Index (RFPI) and Wholesale Food Price Index (WFPI) respectively.

Both the RFPI and WFPI are robust to alternate weighting systems. ${ }^{16}$ We also ensure that they are robust to missing data. ${ }^{17}$ The data we use are not complete and are not reported for specific commodities for specific dates. This is in part because the consumption basket itself varies significantly across cities owing to strong regional preferences and in part due to gaps in reporting. In this analysis we use all the data available and adjust the weights accordingly to account for missing data. Our index, the RFPI and WFPI, are different from the standard CPI for Food computed by the Government of India and as such the two are not directly comparable, both with respect to the method used to compute the index and in the coverage of the commodities. ${ }^{18}$

Apart from examining the trends in RFPI and WFPI, we also assess the gap between wholesale and retail prices. If there are frictions in the market in the transport and delivery of produce to urban markets, one would expect a larger difference between wholesale and retail prices. The gap would also increase if retailers choose to charge consumers higher prices, taking advantage of the limited options consumers might have. Here, we compute Centre-date-Item specific differences between Retail and Wholesale Prices and aggregate them by first weighting commodities and then applying population weights to aggregate these over the centres.

We also compare the movement of the RFPI and WFPI across commodities and contrast patterns across cities. We classify cities into Megacities, Million-plus cities, Class 1 cities/towns and "small" cities, based on the Census $2011 .{ }^{19}$ In the narratives of the consequences of the lockdown, focus

\footnotetext{
16 The correlation between the Retail CPI index with NSS (quantity), NSS (value) and NSS (State-weights) is $0.9227,0.9204$, and 0.9228 respectively. Similarly, correlation between the Wholesale CPI with NSS (quantity), NSS (value) and NSS (State-weights) is $0.887,0.883$, and 0.893 respectively.

${ }^{17}$ For CPI retail, the correlation is 0.9980 between the pooled and non-missing value indices. Similarly, for CPI wholesale, the correlation is 0.9943 between the pooled and non-missing value indices.

${ }^{18}$ For the approach the Government uses to construct the CPI, see CSO(2010).

19 In different documents Class 1 (cities with more than 100,000 people) is based on the Census 2011 nomenclature and the list of million-plus cities is based on the Census 2011 as well.Appendix 4, Census 2011 Primary Census Abstract http://censusindia.gov.in/2011census/PCA/A4.html. The million plus cities are identified in http://censusindia.gov.in/2011-provresults/paper2/data_files/india2/Million_Plus_UAs_Cities_2011.pdf
} 
has been mostly on the large cities, metropolises and little is known about smaller towns and urban centres. Our goal is to see if these cities have seen similar movements in prices as the large cities. ${ }^{20}$

Most of the analysis here focuses on a window spanning a few weeks before the lockdown period until April 21, 2020. As we map the trend in prices during this window, it is useful to bear in mind the context of food price movements in India. The year 2019, India saw significant food inflation, especially during the second half of the year. The late 2019s saw onion prices rise significantly contributing disproportionately to high food inflation. However, since January 2020, overall food inflation has been on a fairly consistent downward trend. The lockdown thus came at a time when retail food prices were trending downwards. In general, this has been the trend globally as well, as indicated by the FAO's Global Food Price Index (Figure 1). In this context, the dominant sentiment among Indian policy makers was that food prices are likely to decline further given the economic shock associated with the lockdown (reported by Suneja and Noronha, 2020, for example). Data released in April suggests that food inflation for March was 8.76 per cent as against 10.81 per cent in the previous month leading to a sense that food prices were easing off. ${ }^{21}$ The lockdown has reversed this trend.

Figure 1: FAO's Global Food Price Index and India's Consumer Price Index for Food, 2019-20

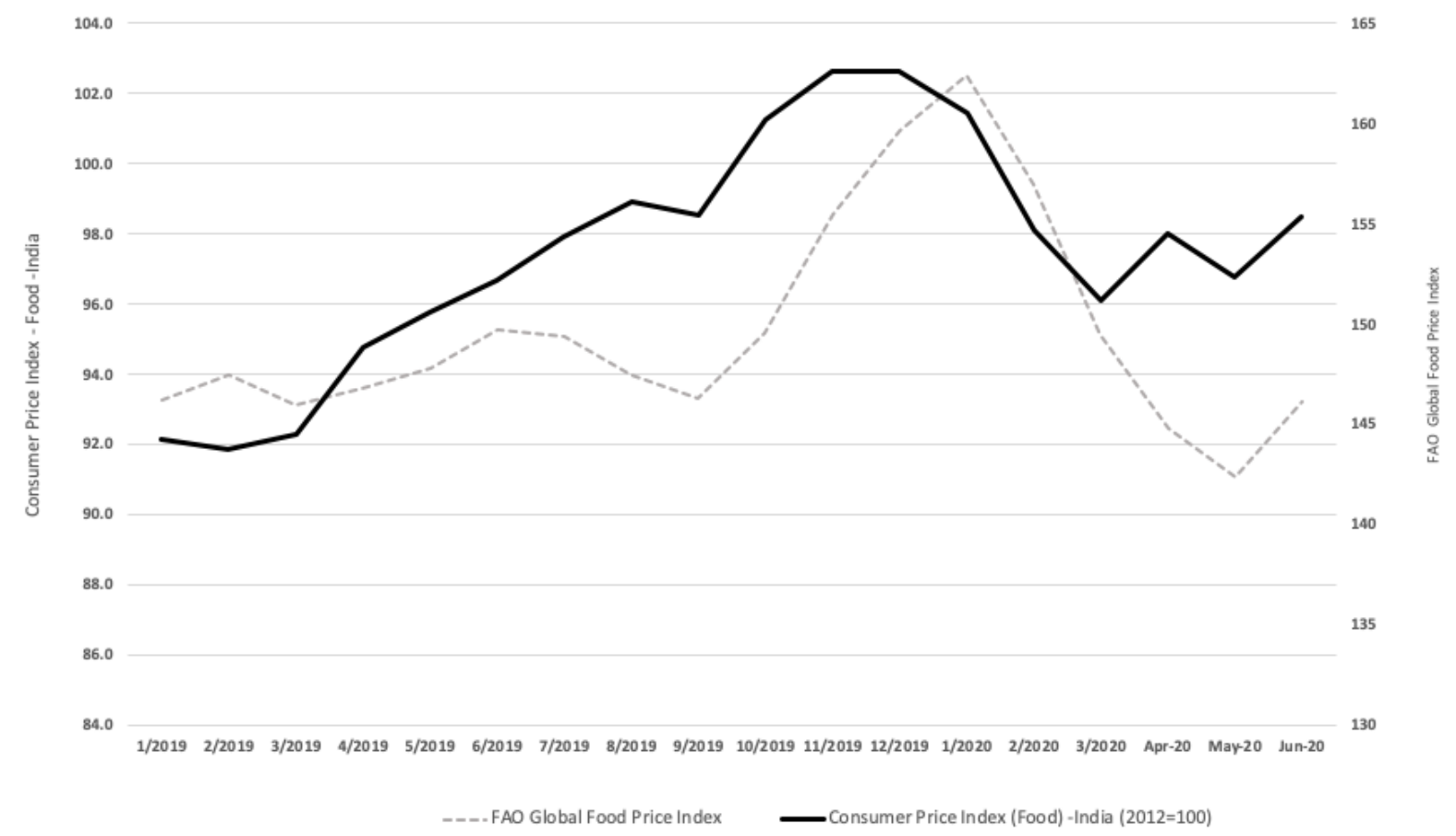

Source: Reserve Bank of India and The Food and Agriculture Organisation; FAO's index uses 2014-16 as base.

\footnotetext{
${ }^{20} \mathrm{We}$ also assess separately states that went in for an early lockdown ahead of the national lockdown. Some states such as Kerala, Tamil Nadu, Uttar Pradesh (17 districts) announced a lockdown on March 22, 2020. We do not find a significant difference however and hence do not present these here.

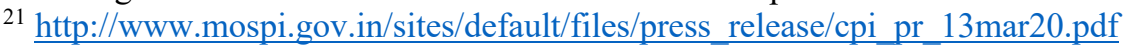




\subsection{Results}

Figure 2 plots the Retail and Wholesale Food Price Index. With both RFPI and WFPI, there is a clear dip around the time of the March 22, 2020, which was the "Janata Curfew", also a Sunday. The RFPI however increases immediately after lockdown, reversing a two-month long downward trend in the RFPI. WFPI too shows a perceptible increase soon after lockdown. The increase after March 24, 2020, is not apparent in the previous two years, suggesting that this is indeed likely due to the lockdown. ${ }^{22}$ Towards the end of May, it appears that wholesale prices seem to decline to its pre-lockdown trend, retail prices are not declining as fast. Figure 3, which maps the price gap between retail and wholesale, expressed as a percentage of wholesale prices shows a dramatic increase post-lockdown, suggestive of increased transactions costs for retailers or greater retailer power to set prices or both.

As one would expect, not all commodity prices have increased comparably (Figure 4; Table 1). All the pulses and most edible oils, sugar and salt register significant increases. The prices of potato and tomato too have increased significant during the lockdown, although it appears that the increase is not sustained for tomato. Onion prices have increased although it continues to remain low relative to the prolonged period of high prices in late 2019. Milk prices however seems to have held, as does loose tea and palm oil. The government had urged importers to boycott palm oil imports from Malaysia in February and despite no official ban, imports were curtailed. ${ }^{23}$ This is reflected in the increase in prices during February, it has continued to remain at high levels and there is no expectation that imports from Malaysia will expand any time soon. Price increases are to the tune of over $6 \%$ for several pulses, over $3.5 \%$ for most edible oils, $15 \%$ for potato $28 \%$ for tomato (Table 1 ). For the commodities that have seen a significant increase, although the prices have plateaued, only a few are reverting to pre-lockdown level.

Another aspect of food prices is spatial dispersion across cities. Given the restrictions on transport across and within many states, one would expect that markets are today geographically segmented. Typically, when there are price differences across two locations, private traders would take advantage of arbitrage opportunities and move produce to the location with higher prices. This expansion of supply in markets where price reigns high would occur until the difference reduces to the extent that there are transport costs. When this mechanism is disrupted, as it has during the lockdown, one would expect a large difference in prices spatially. This is indeed what has happened post-lockdown - our estimates show that standard deviation of the RFPI and WFPI across cities increased three times (from 0.6 to 1.9 and 1.3, on average, respectively between the pre-and post-lockdown period). It is noteworthy that relative to the RFPI on the eve of the lockdown, the RFPI rise as been has high as $20 \%$ in some centres with others seeing RFPI decline by 5\% (Figure 5). The rise in RFPI at rates more than

\footnotetext{
${ }^{22}$ Some states announced lockdowns earlier than March 24, 2020. We do not find any significant difference between the early and national lockdown states.

${ }^{23} \mathrm{https} / /$ www.reuters.com/article/us-india-malaysia-palmoil-exclusive/exclusive-india-urges-boycott-ofmalaysian-palm-oil-after-diplomatic-row-sources-idUSKBN1ZC0T6
} 
$15 \%$ is disproportionately among small towns and Class 1 cities/towns. We know little about the specific conditions in these cities, but it is instructive that some cities are seeing a worrying increase in retail food prices. Much of the media accounts of disruptions in urban food markets have focused on the largest cities. Yet, we find that smaller cities seem to have more pronounced impacts and register sharper increase in prices that the average (Figure 6).

These results of a price increase are at odds with many commentaries in India, published during the lockdown, on the likely direction of food price movements. One key reason is that these predictions anticipated that demand collapse would suppress prices. While the demand effect (especially the closure of eateries, restaurants and social events as well as the exodus of migrants) have dominated in some cities, it appears that supply shocks to food markets have been more powerful in the lockdown period and have therefore had the opposite effect on prices, on average, and especially pronounced in some cities. In general, although expectations are that over the medium term, prices likely would go down, due to lacklustre demand and economic activity, these results suggest that food prices would rise in the short term, before they fall.

\section{Figure 2: Retail and Wholesale Food Price Index in India pre- and post-lockdown}
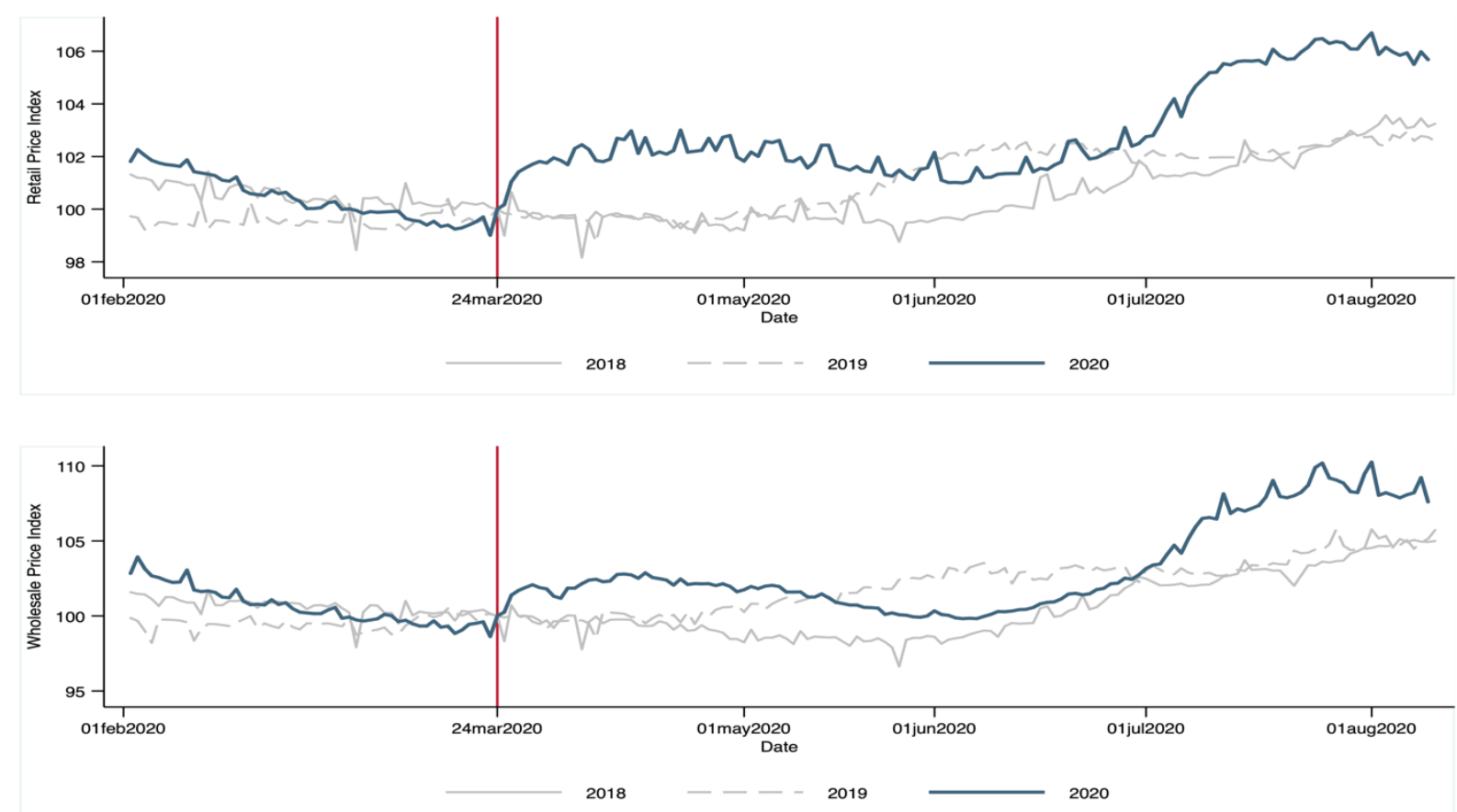

Source: Computed by the authors. March 24 of each year has been set at 100 to facilitate comparison across years. 
Figure 3: Average gap between retail and wholesale prices in Food items before and after the Lockdown

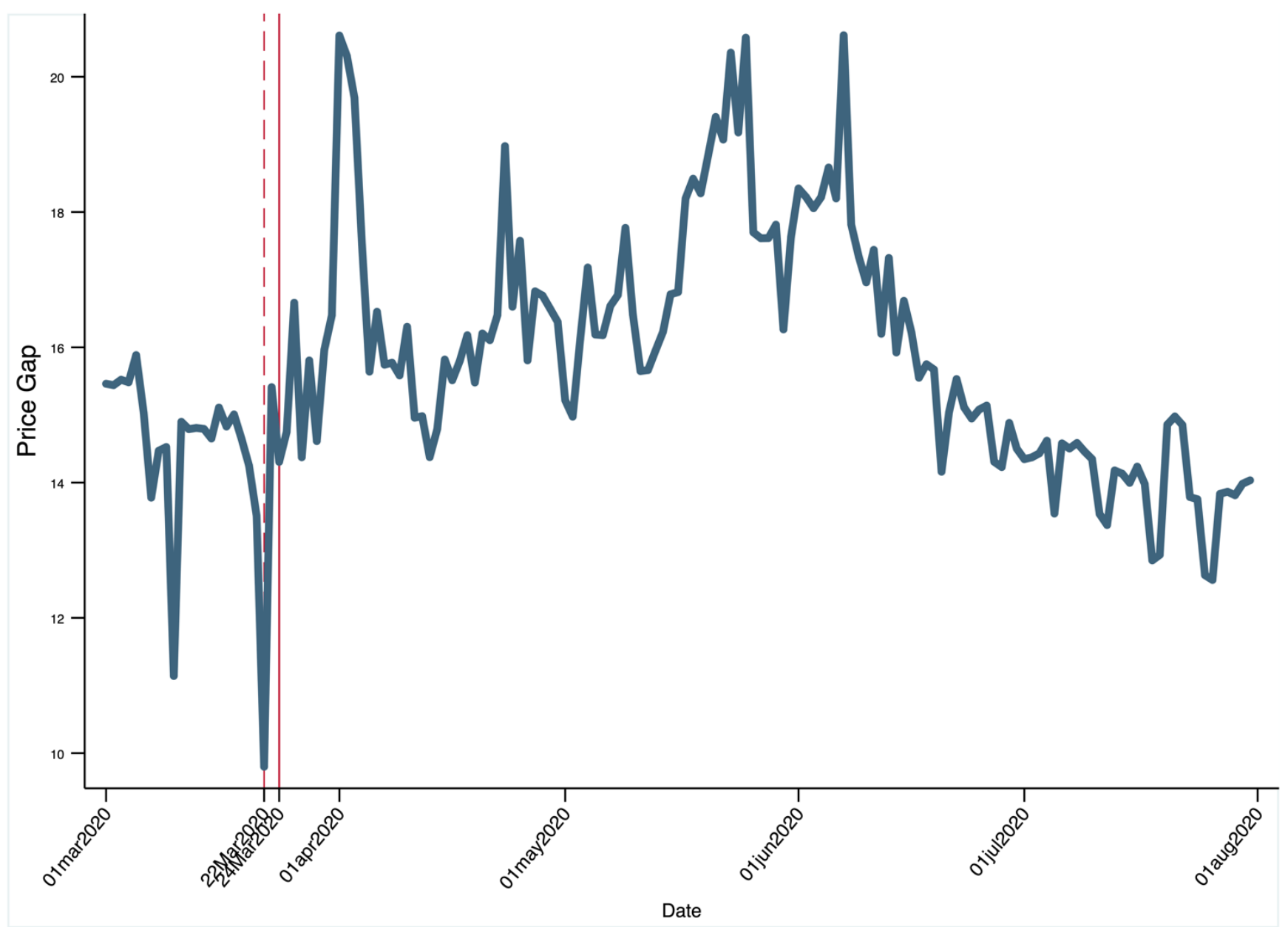

Source: Computed by the authors. This gap is computed as (Retail price-Wholesale price)/Wholesale Price X 100 for each Centre, date and item. The gap is then weighted by commodity and then by city population to get an AllIndia average. 
Figure 4: Variation in wholesale /retail price movements across Food items (average Rs./kg)
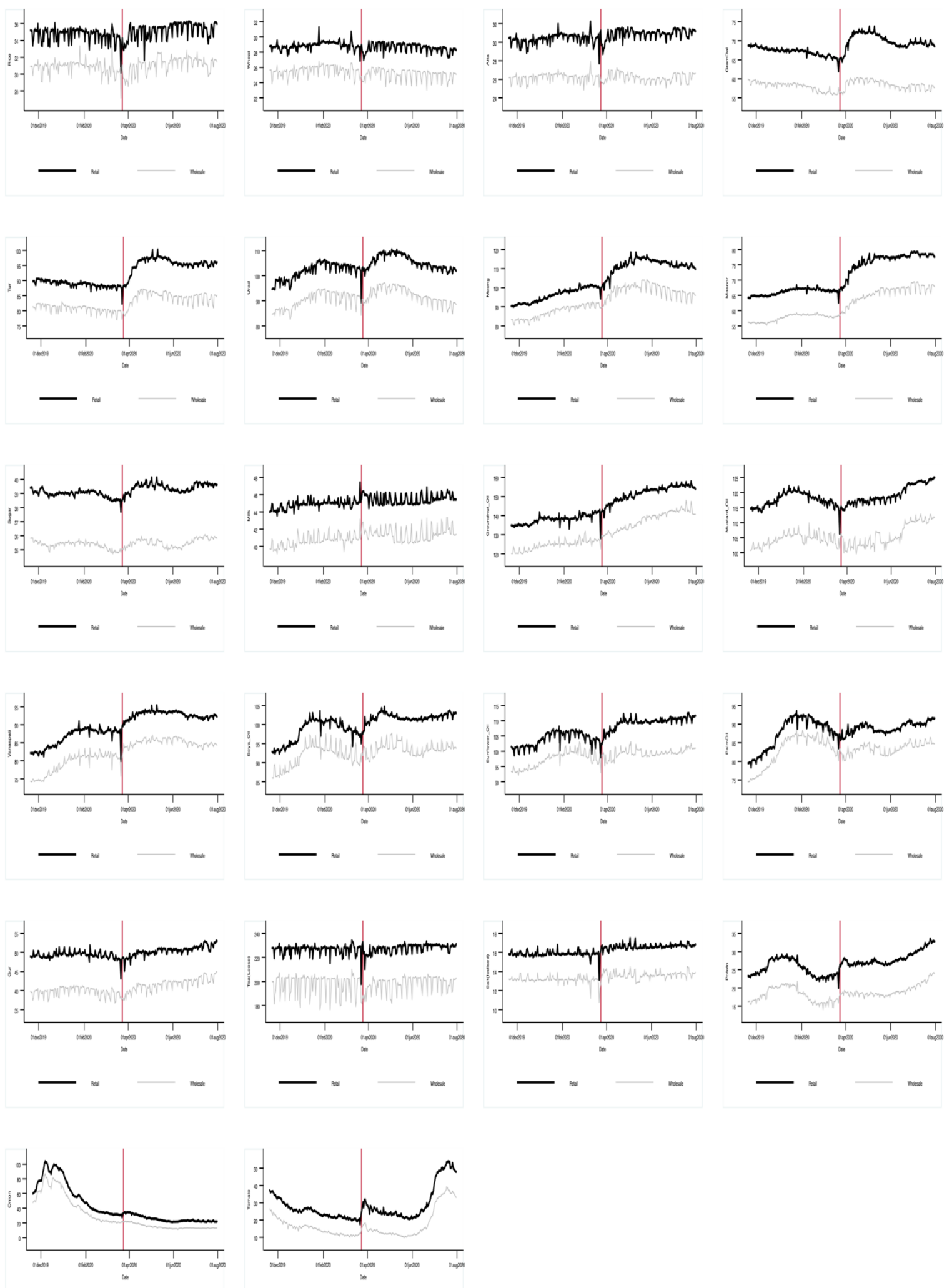

Source: Computed by the authors. These plots are for the period starting December 1, 2019 to illustrate the longer trend in prices. THe gray line denotes wholesale prices, black line denotes retail prices. 
Table 1: Change in average, minimum and maximum price for a 4 week period before and after lockdown.

\begin{tabular}{|c|c|c|c|c|c|c|}
\hline Commodity & Retail Price & change (\%) p & t versus pre & Wholesal & Price change & $(\%)$ \\
\hline & $\begin{array}{l}\text { Average } \\
\text { price }\end{array}$ & $\begin{array}{l}\text { Minimum } \\
\text { price }\end{array}$ & $\begin{array}{l}\text { Maximum } \\
\text { price }\end{array}$ & $\begin{array}{l}\text { Average } \\
\text { price }\end{array}$ & $\begin{array}{l}\text { Minimum } \\
\text { price }\end{array}$ & $\begin{array}{l}\text { Maximum } \\
\text { price }\end{array}$ \\
\hline Rice & 0.98 & 8.71 & 0.36 & -0.1 & 5.14 & -3.80 \\
\hline Wheat & -0.61 & 0.29 & -4.04 & -0.4 & 0.83 & -2.03 \\
\hline Atta & 0.54 & 3.52 & -2.26 & 0.5 & 2.57 & -2.47 \\
\hline Gram & 6.37 & 3.90 & 9.79 & 4.4 & 0.20 & 3.97 \\
\hline Tur & 6.38 & 6.80 & 10.15 & 5.0 & 1.68 & 8.21 \\
\hline Urad & 2.87 & 11.92 & 4.48 & 2.3 & 4.60 & 3.22 \\
\hline Moong & 6.77 & 4.91 & 11.46 & 6.1 & 1.46 & 9.32 \\
\hline Masoor & 8.00 & 6.62 & 13.17 & 6.3 & 2.42 & 9.08 \\
\hline Groundnut Oil & 3.99 & 8.54 & 4.43 & 3.1 & 4.92 & 1.44 \\
\hline Mustard Oil & 0.28 & 7.36 & -0.08 & -1.6 & -1.62 & -1.52 \\
\hline Vanaspati & 4.78 & 12.01 & 4.25 & 4.3 & 9.21 & 3.66 \\
\hline Soya Oil & 3.61 & 4.05 & 4.54 & 1.7 & 1.26 & 1.55 \\
\hline Sunflower Oil & 3.34 & 4.93 & 4.36 & 0.4 & 2.30 & 0.79 \\
\hline Palm Oil & -0.54 & 2.58 & -0.54 & -1.9 & -0.09 & -3.60 \\
\hline Milk & 0.97 & 0.11 & -2.12 & 1.7 & 3.59 & -0.76 \\
\hline Sugar & 1.79 & 1.96 & 2.38 & 1.4 & 0.70 & 1.61 \\
\hline Gur & 0.92 & 4.70 & 0.40 & 2.4 & 1.69 & 2.83 \\
\hline Loose tea & -0.76 & 6.25 & -1.70 & -0.5 & 2.36 & -2.90 \\
\hline Iodised salt & 4.78 & 20.16 & 3.08 & 5.7 & 18.64 & 3.79 \\
\hline Potato & 15.67 & 29.54 & 6.90 & 14.6 & 25.37 & 5.31 \\
\hline Onion & -0.27 & 2.17 & 1.70 & -7.4 & -13.83 & -5.60 \\
\hline Tomato & 28.88 & 33.83 & 29.13 & 27.5 & 21.41 & 23.02 \\
\hline
\end{tabular}

Source and Notes: Computed by the authors. We use the weighted average price for each commodity for each day, where the weights are city population. We then compute the average, minimum and maximum value for the period of 4 weeks prior to the lockdown and 4 weeks post-lockdown. We compute the change in average, minimum price and maximum prices using this. We do this for wholesale and retail prices. 
Figure 5: Range of RFPIs across Centres

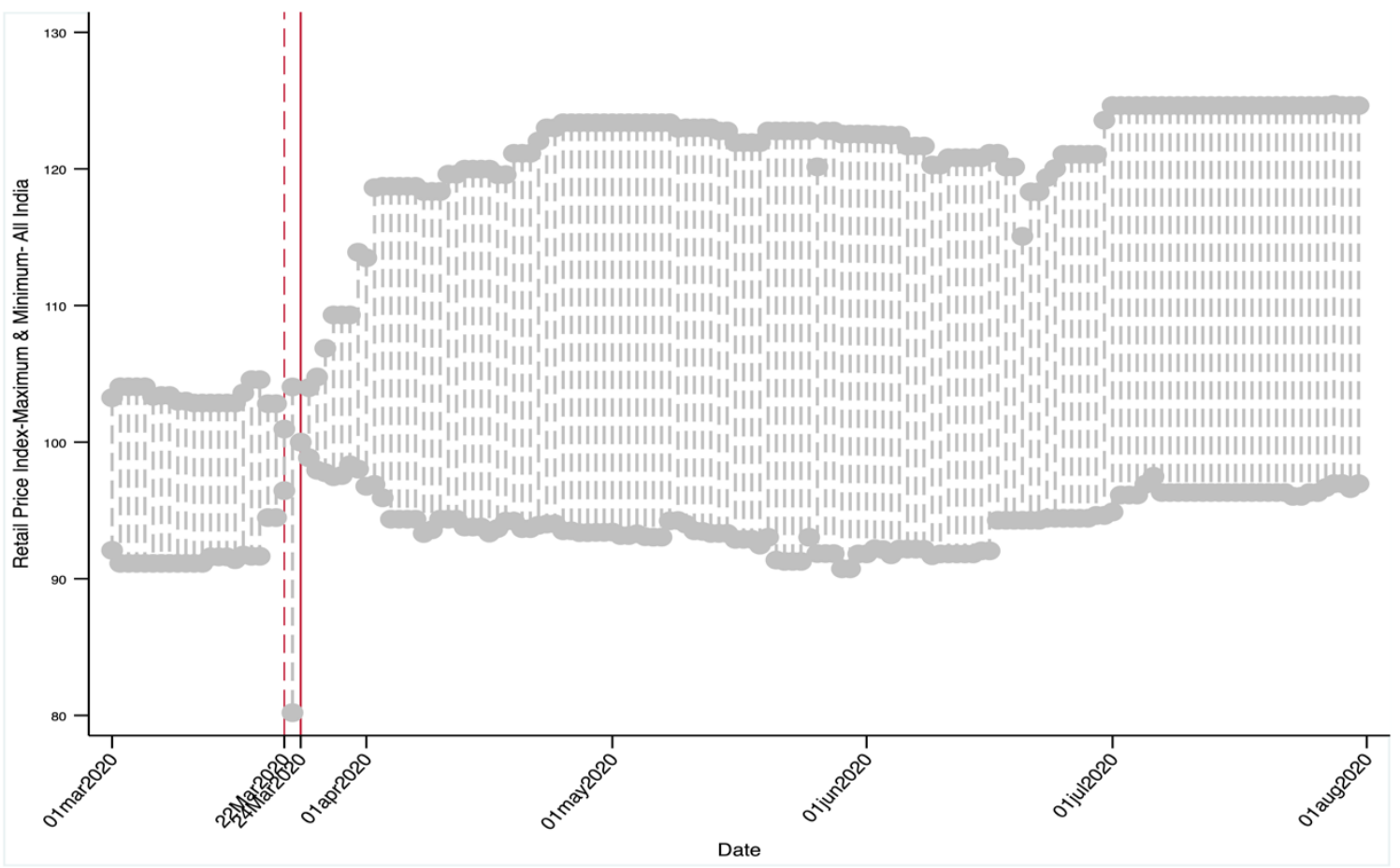

Source: Computed by the authors. This graph plots the maximum and minimum RFPI each day to show the range across Centres/cities. For each centre, RFPI for that centre for March 24, 2020 is held at 100)Figure 6: Smaller cities have seen steeper than average increase in RFPI

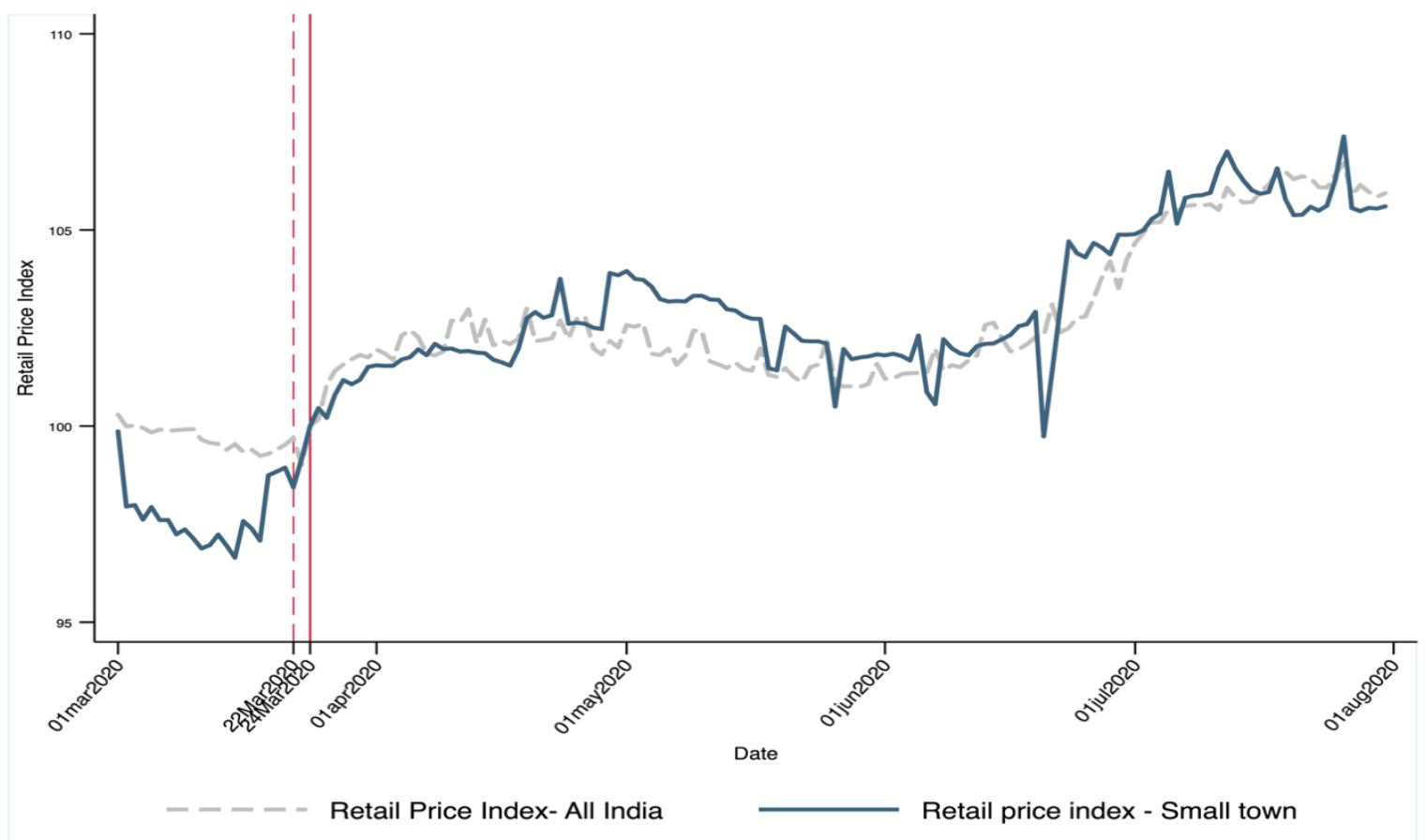




\section{Operational challenges and strategies to overcome them}

To understand these issues of supply bottlenecks faced by various stakeholders, we conducted three rounds of face-to-face surveys of around 50 food retailers at 21 locations in 14 cities across India. They include grocery retailers (kirana stores), retailers of fresh produce, who have temporary stands or pushcarts on streets, as well as of meat retailers who typically have dedicated stalls where meat is cut and prepared. The first round of interviews was conducted between April 6-18, 2020 and each retailer was visited once in this period. A similar exercise was conducted, revisiting the same respondents as far as possible between May 6-26, 2020 and then again during June 10-July 10, 2020. ${ }^{24}$

There is clear evidence of significant supply disruptions (Figure 7) relating to both availability of supplies and transportation. Retailers of fresh produce, typically pushcart or street vendors seemed to be particularly constrained. In big cities such as Bangalore, Delhi and Mumbai, these vendors mentioned that before the lockdown they sourced their supplies of fresh produce from a single wholesale market; now they were forced to go to different locations to source different items, sometimes make multiple trips (3-4) each day to do this. The timings of the wholesale market were also unpredictable. Vendors in both Mumbai and Delhi reported having to procure produce at 2 a.m. in the night, rather than early morning as was practice. Another vendor said that often the supplies were thin and they were often unavailable by the time they could get to the wholesale market. In Mumbai, retailers of fresh produce said that there was considerable uncertainty as to which wholesale market in the city would work each day - so that produce would arrive in one area of the city on one day and another one $20 \mathrm{kms}$ away the next day. These do not seem to have changed much over the one month between the surveys.

For meats, anecdotal accounts suggest that initially the poultry meat in particular faced a huge slump because many consumers associated it with the spread of COVID-19. ${ }^{25}$ Soon after, in some cities, it had become impossible to procure mutton and chicken. Some vendors reported that chicken prices, after a collapse, had more than doubled, had gone up from Rs.100/kg to Rs.220/kg within two weeks in smaller towns, as had mutton prices where they continue to be traded. ${ }^{26}$

Transportation costs had increased substantially, doubled in some cities according to our survey, and was hard to arrange. Grocery retailers mentioned that restocking had become harder.

\footnotetext{
${ }^{24}$ These interviews were challenging because of movement restrictions during the lockdown and because of uncertainty around opening times and vendor availability. We kept the interviews short and focused on their operations. We could revisit only 34 of the same retailers in the second round, with 6 new retailers.

$25 \mathrm{https}$ ://www.timesnownews.com/india/article/lockdown-what-happens-if-you-don-t-have-chicken-or-muttonfor-some-days-sc-asks-petitioner/578542

${ }^{26}$ Interestingly, as part of the PIL referred to earlier, the Writ Petition (Civil) No(s). 10894/2020 heard on 15 April 2020, Amit Goyal versus the Union of India, had requested chicken mutton be included in essential food and drink items. The guidelines issued by the MHA already permits these, but the contention was that police were harassing the petitioner when he went to sop for meet. The Judge is reported to have asked "what will happen if we do not eat chicken and mutton for a few days?" while dismissing the petition.
} 
Stocks of branded dry goods had also dwindled as companies were no longer sending refill vans with their products. A store owner in Latur, Maharashtra, said while demand for biscuits and bakery products demand had gone up, supply of these had dried up. A few kirana store owners indicated that due to supply constraints, wholesalers had raised prices of most commodities. Some retailers also mentioned that they were now stocking fewer items. In the early days of the lockdown, people had hoarded rice, wheat flour and oils and they felt that there was no demand any longer and had therefore stopped stocking them. In general, most felt that demand was lower after the initial days. Close to a third felt overall demand had gone down relative to business as usual. While some said they were passing on the higher costs they faced on to consumers, others said they were absorbing the losses and not charging consumers a higher price.

Even as supply was a huge problem, store owners and retail street vendors mentioned that they were allowed to do business only for limited hours. Most reported that the police ensured that they closed after 5 or 6 p.m. Retailers of fresh produce found this to be a constraint since their operating house were usually till 10 p.m. Even after two months under the lockdown, these restrictions had not eased and store owners felt that rather than restricting working hours, it would be easier for them to manage crowds if they were allowed to keep longer hours and do more business.

A disproportionate number of street vendors of fresh produce complained that the police frequently stopped them and many complained of harassment. Sourcing produce from wholesale markets in the middle of the night was particularly difficult. Typically, the police demanded a "moving pass" but these permits were difficult to get and many did not know how to obtain them. ${ }^{27}$ Other vendors were harassed for either setting up shop or for not ensuring physical distancing amongst consumers. Street vendors of fresh produce were far more likely to face such harassment than kirana shop operators, although the kirana shop owners too reported that the police visited frequently to ensure that the shops were not crowded. By May 2020, while some bottlenecks had eased, labor shortages, high transportation costs and local restrictions and harassment by police were identified as key challenges. Supply of fresh produce continued to be a problem (Figure 7).

Street vendors of fresh produce were however adapting to the new situation. Interestingly in many cities, many migrant workers or those were doing other business have now switched to selling fruits and vegetables, given the low entry barriers to informal retail vending. In Porvorim, Goa, for example, a fruit vendor pointed that around 30 people from the locality they are staying in have opened up fruit shops because they are out of work and could not return to their villages in neighboring Karnataka. A garage mechanic, forced to shut his shop, had switched to selling fresh produce.

\footnotetext{
27 A March 26, 2020 notification of standard operating procedure issued by the Ministry of Home Affairs noted "In case of unorganized sector, persons engaged in the supply of essential goods may be allowed based on approval/authorization by the local authorities." Few street retailers of produces were aware of what was required.
} 
Many who had stalls had now either begun to use pushcarts or had begun to set up temporary stalls in residential complexes, since consumers could not venture out to shop as much. One vendor in Hazaribagh, who has been doing business for 30 years, noted that the number of cart vendors of vegetables and fruits has increased significantly. He felt that in the wholesale market, from where he sources produce, the number had perhaps gone up five-fold, from 50 pre-lockdown, to 250 postlockdown. He also felt that the new pushcart vendors had captured much of the market share from "fixed stall" sellers, since they were mobile and consumers were not. In Noida, Uttar Pradesh near the national capital of New Delhi, one vendor observed that the competition had increased with an increase in the number of pushcart retailers of fresh produce, observing that this cut into each person's earnings. In the smaller cities, some retailers suggested that they were helpless indicating that they may not be able to continue with so many restrictions in movement and hours of business with consequently very little sales. Indeed, not all food retailers are able cope. In the smaller cities, some pushcart retailers suggested that they were considering returning to their native villages.

By May, when we attempted to contact the same retailers, at least six of the pushcart/ street vendors had stopped selling or had not been doing so regularly on account of difficulties. Of those interviewed, an overwhelming proportion said that operational challenges continued unabated. In contrast, grocery store merchants indicated that despite the fact that they continued to pay a high price for products, things had improved. Over two-thirds of our sample said that they had suffered losses on account of the lockdown, a fifth said their earnings was less than half. However, this was disproportionately among street vendors. Among grocery store owners, a fifth mentioned that their earning had increased significantly, since consumers had to depend on them rather than supermarkets located in malls, due to closures. E-commerce and online delivery firms too were unable to service all their consumers leading them to rely on local stores and vendors.

All the retailers seemed to be aware of Covid-19 and virtually all of them, barring two, stated that they were taking precautions to ensure physical distancing. Most store owners were now serving customers at the door step, forbidding entry into the store. Those that did allowed one person or a few, depending on the size, into the store at a time. Some kirana stores mentioned that they were only allowing customers who came with a specific list who could place their order quickly in order to be able to service more clients. Those who were undecided and scanned the shop to see what they wanted were discouraged. Many pushcart and street side fresh produce vendors kept their produce covered.

As part of the survey we also collected prices of key items. Table 2 presents these prices and compares these to prices from the government data for the same time period April 6-18, 2020. ${ }^{28}$ Consistently, it is evident that for most commodities, the prices collected as part of the survey tend to

\footnotetext{
${ }^{28}$ For horticultural commodities, we compare the prices with the National Horticulture Board prices, though these were available only for one centre Badaun in Uttar Pradesh; we therefore use prices from a commercial website. These come with caveats on data reliability since it is unclear how these prices have been collected.
} 
be higher and show a larger range than the average retail prices for the country. This offers a modest confirmation of official prices, while suggesting that price rise might be greater than official data suggest (Table 2). At the same time, for the cities we survey, average prices for most commodities, particularly fresh produce had dropped over the month between the surveys.

Figure 7: Operational challenges of food retailers $(\mathbf{N}=\mathbf{5 0})$

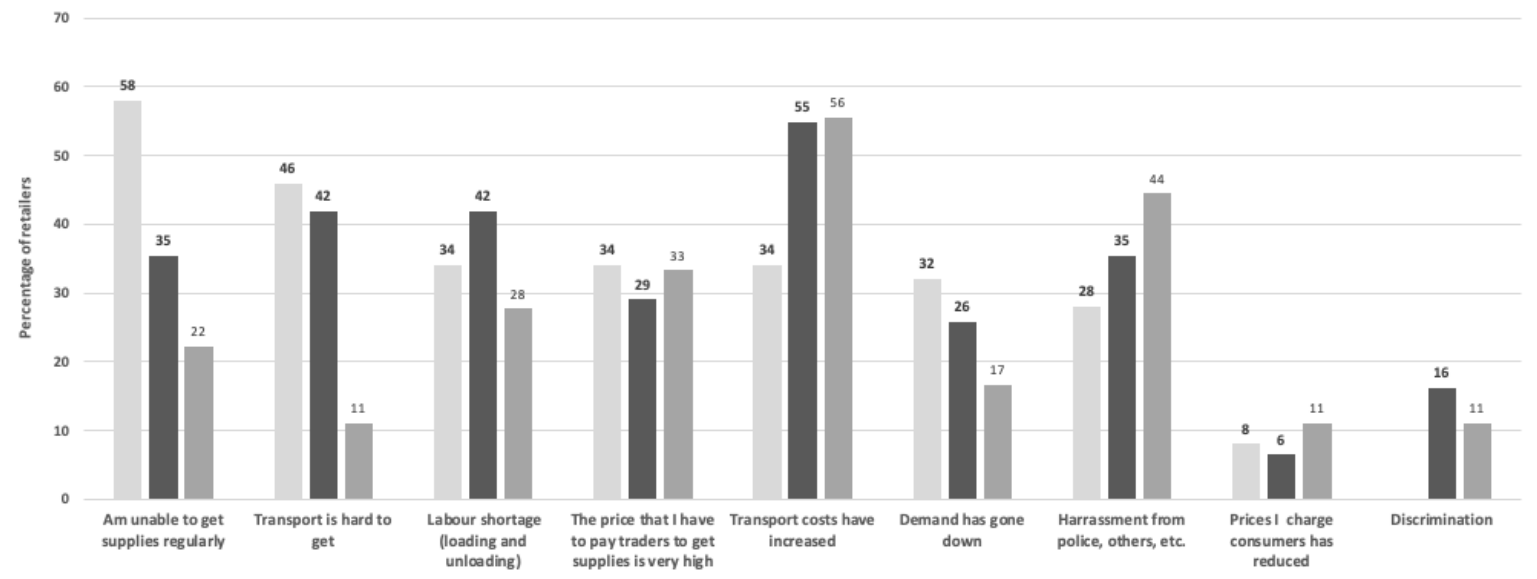

Source: Computed based on the survey 


\begin{tabular}{|c|c|c|c|c|c|c|c|c|c|c|}
\hline \multirow[b]{2}{*}{ Item } & \multicolumn{3}{|c|}{$\begin{array}{l}\text { Food Price Survey -Round } 1 \text { (April 6-18, } \\
\text { 2020) }\end{array}$} & \multicolumn{3}{|c|}{$\begin{array}{c}\text { Food Price Survey -Round } 2 \text { (May 6-25, } \\
2020)\end{array}$} & \multirow[t]{2}{*}{$\begin{array}{c}\% \text { change in } \\
\text { average between }\end{array}$} & \multicolumn{3}{|c|}{$\begin{array}{l}\text { Government data (April 6-May } \\
25,2020 \text { ) }\end{array}$} \\
\hline & Average & Minimum & Maximum & Average & Minimum & Maximum & & Average & Minimum & $\begin{array}{c}\text { Maxim } \\
\text { um }\end{array}$ \\
\hline $\begin{array}{l}\text { Rice (not basmati, not par-boiled) Rs. per } \\
\text { kilogramme }\end{array}$ & 46 & 30 & 73 & 51 & 32 & 80 & 12 & 35 & 32 & 36 \\
\hline Wheat (Rs. per kilogramme) & 35 & 30 & 42 & 40 & 22 & 56 & 13 & 29 & 27 & 29 \\
\hline Atta (Rs. per kilogramme) & 39 & 25 & 62 & 46 & 25 & 130 & 17 & 31 & 30 & 32 \\
\hline $\begin{array}{l}\text { Tur dal/ arhar /pigeon pea (Rs. per } \\
\text { kilogramme) }\end{array}$ & 116 & 70 & 166 & 106 & 80 & 130 & -8 & 97 & 94 & 100 \\
\hline Channa dal (Rs. per kilogramme) & 93 & 65 & 126 & 79 & 54 & 116 & -15 & 72 & 70 & 74 \\
\hline Sunflower oil (Rs. per liter) & 126 & 100 & 200 & 117 & 100 & 140 & -7 & 109 & 106 & 112 \\
\hline Mustard Oil (Rs. per liter) & 119 & 108 & 140 & 118 & 110 & 135 & -1 & 117 & 115 & 119 \\
\hline Milk (Rs. $500 \mathrm{ml}$ pouch) - skimmed, toned & 25 & 19 & 32 & 25 & 19 & 40 & 1 & 45 & 45 & 46 \\
\hline Eggs (Rs. per dozen) & 73 & 48 & 180 & 61 & 48 & 78 & -16 & & & \\
\hline Chicken (Rs. per kilogramme) & 200 & 110 & 320 & 186 & 110 & 300 & -7 & & & \\
\hline Mutton (Rs. per kilogramme) & 678 & 400 & 1000 & 618 & 400 & 850 & -9 & & & \\
\hline Tomato (Rs. per kilogramme) & 28 & 12 & 60 & 23 & 10 & 40 & -19 & 24 & 21 & 28 \\
\hline Potato (Rs. per kilogramme) & 33 & 19 & 40 & 33 & 20 & 48 & 0 & 27 & 26 & 28 \\
\hline Onion (Rs. per kilogramme) & 34 & 20 & 50 & 23 & 10 & 40 & -32 & 27 & 22 & 34 \\
\hline $\begin{array}{l}\text { Green leafy vegetables (any type palak, } \\
\text { etc.) Rs. per bunch }\end{array}$ & 23 & 7 & 60 & 21 & 5 & 40 & -8 & 19 & 14 & 23 \\
\hline Eggplant (Rs. per kilogramme) & 43 & 15 & 80 & 37 & 20 & 80 & -13 & 45 & 29 & 57 \\
\hline Cauliflower (Rs. per kilogramme) & 36 & 15 & 55 & 35 & 20 & 60 & -2 & 36 & 23 & 44 \\
\hline Banana (Rs. per dozen - fair quality) & 61 & 15 & 110 & 54 & 20 & 80 & -11 & 61 & 46 & 70 \\
\hline Papaya (Rs. per kilogramme) & 54 & 25 & 100 & 42 & 30 & 60 & -22 & 42 & 35 & 47 \\
\hline Santra/ orange (loose jacket) (Rs.) & 80 & 40 & 120 & 68 & 40 & 110 & -15 & 74 & 52 & 89 \\
\hline
\end{tabular}


The narratives from our survey of urban food retailers is consistent with reports on operational challenges in food retail published in credible newspapers across the country. Although the central government clarified on March 29, 2020 and issued an order indicating that grocery stores could remain open throughout the day or night, our survey suggests that on the ground not much appears to have changed, an issue that the Government of India itself seemed to be aware of. On April 3, 2020, the Government of India was even pushed to ponder the meaning of food and grocery:

\begin{abstract}
Queries have been received as to what constitutes food and grocery. Since it is neither feasible nor desirable to mention each item of food and grocery in the guidelines, the State/UT Governments have been advised to interpret these terms to mean all items of food and grocery that are usually consumed by people on day to day basis.
\end{abstract}

Several instances of social discrimination have emerged recently in many cities, where pushcart retailers of fresh produce who are from minority religion have been denied access to neighborhoods where they typically sold produce. ${ }^{29}$ In our follow up survey, for example, about six of those interviewed mentioned that they had experienced some form of discrimination. One pushcart vendor from our survey noted that his customers from one religious group had switched to another seller, citing his religion as a factor. There have also been instances where supermarket retailers have refused to allow entry to customers from specific ethnic backgrounds. ${ }^{30}$ These disturbing instances reflect systemic discrimination and deserve further scrutiny and documentation.

In response to the formidable challenges associated with food retail during the lockdown, several new initiatives have emerged. For example, many farmers, braving the lockdown, have taken to delivering produce directly using WhatsApp to secure aggregated orders in housing societies. ${ }^{31}$ Other farmers chose to travel to the cities to set up shop at roadsides. Consumer-led Groups on Twitter, Facebook and What's App such as Harvest Farmer Initiative (HFI) and Farmer to Fork have emerged specifically to address farmer distress. The former lists on Twitter details of farmers who are in distress along with the produce they wish to sell so that consumers can arrange to procure directly from farmers. The latter aggregates consumer demand via Facebook to source from farmers. Alumni of the University of Agricultural Sciences in Bangalore similarly set up a platform to assist grape farmers in getting produce to the city. ${ }^{32}$ Several other not-for profit and for-profit agritech platforms such as Krishihub, Agrostar, Ninjakart and Jumbotail (Thaker, 2020) have performed a critical role in

\footnotetext{
${ }^{29} \mathrm{https}: / / \mathrm{www} \cdot$ thehindu.com/news/national/other-states/activists-condemn-discrimination-against-muslimvendors/article31349219.ece

${ }^{30}$ https://www.livemint.com/news/india/covid-19-people-from-northeast-face-discrimination-in-karnataka$11585479540806 . \mathrm{html}$

${ }^{31}$ https://timesofindia.indiatimes.com/city/pune/farmers-bring-fresh-packed-veggies-fruits-todoorstep/articleshow/75227386.cms

32https://www.deccanchronicle.com/nation/in-other-news/180420/bengaluru-grape-farmers-go-direct-toconsumers-and-movement-spreads-1.html
} 
restoring the broken links of the food supply chain. Farmer Producer Organisations (FPOs) too have taken the lead in aggregating produce of members to supply to clients in cities and small towns (Vrutti \& Arya, 2020). In some southern states, governments have been actively procuring horticultural produce from FPOs for distribution including home delivery. E-delivery services like Swiggy, Zomato, that typically delivered food from restaurants, have pivoted to delivering groceries and many local informal dairies, restaurants and sweetshops began supplying groceries and fresh produce via these platforms. ${ }^{33}$ Several online retail platforms tied up with the local corner stores to deliver essentials. ${ }^{34}$ Furthermore, to facilitate the delivery to food (both grocery and cooked) during the lockdown, these online platforms allowed customers to make personalized orders from any store of their convenience for a very small fee. ${ }^{35}$ These examples, though likely small in scale and limited in reach, suggest a capacity for innovation and resilience in response to severe disruptions associated with the lockdown. ${ }^{36}$

Many recent accounts of Indian food retail note the emergence of large-scale online grocery and produce delivery establishments. During the lockdown, several of them had been forced to suspend operations, in part because their delivery agents encountered problems with local police but also because with the large-scale migration out of cities, many found it hard to recruit delivery staff. In general, larger online grocery retailers had resumed operations, by the end of the lockdown, expanding their workforce by hiring workers from other sectors, but were struggling to match consumer demand. ${ }^{37}$ Industry observers suggest that while online food delivery orders (referred to as "foodtech") dropped by 75\% in April 2020, relative to January 2020 (e-commerce fell by 83\% over this period), e-grocery in contrast rose by $27 \%{ }^{38}$ Despite sophisticated procurement and stocking systems, this segment were unable to function effectively (Mahajan and Tomar, 2020, for example) and only a fraction of the orders were fulfilled due to distribution challenges, including labor availability. By contrast, most note the resilience of the kirana store and informal street retailers. ${ }^{39}$

\footnotetext{
$33 \mathrm{https}$ //www.indiatoday.in/technology/features/story/swiggy-zomato-and-other-apps-delivering-groceries-inindia-everything-you-need-to-know-1666703-2020-04-14

${ }^{34} \mathrm{https}$ ://www.livemint.com/industry/retail/retail-india-set-for-a-recast-as-e-tailers-woo-kiranas11587668948307.html as accessed on May 29,2020

$35 \mathrm{https}$ ://www.financialexpress.com/industry/sme/swiggy-to-launch-new-service-staples-plus-to-offer-credit-torestaurants/1972562/ as accessed on May 29,2020

$36 \mathrm{https}$ ://economictimes.indiatimes.com/small-biz/startups/newsbuzz/pandemic-gives-swiggy-grofers-amazonshyperlocal-models-a-new-lease-of-life/articleshow/75075453.cms

37 https://www.spglobal.com/marketintelligence/en/news-insights/latest-news-headlines/covid-19-compoundschallenges-for-amazon-walmart-in-india-58108050

${ }^{38}$ https://redseer.com/newsletters/how-did-covid-19-impact-india-internet-and-whats-the-way-forward/

$39 \mathrm{https}$ ://www.livemint.com/industry/retail/the-neighbourhood-kirana-store-makes-a-roaring-comeback-thisseason-11586545799321.html
} 


\section{Concluding remarks}

Discussions on the critical trade-offs between controlling the pandemic and economic distress associated with measures such as lockdowns have drawn a lot of attention recently (Ray et al., 2020). Most suggest that there is a need to manage both and that these should not be viewed as one or the other or as a commentator put it as a "Faustian bargain". The lockdown clearly left urban food markets in disarray. Despite guidelines that allow the movement and transactions in essential commodities, it appears that law enforcement and the bureaucracy have privileged maintaining the lockdown over maintaining food security, which has been compromised severely. Surveys during the lockdown suggest that of the 11,159 workers surveyed by a migrant support network, an estimated $96 \%$ did not get rations from the government, $72 \%$ said that their rations will get over in 2 days and $90 \%$ did not get wages (SWAN 2020). While the entire country was under a lockdown, those in urban areas were likely more vulnerable than those in rural areas. A survey by NCAER shows that while $57 \%$ of the respondents in urban areas reported that the lockdown caused a large dip in their income sources, only $48 \%$ of individuals in urban areas had access to any social security, in terms of additional grains or cash, in comparison to $66 \%$ individuals in the rural areas (NCAER, 2020). The loss of income coupled with lower availability of safety nets in the urban areas adds to the growing concerns that these areas may be disproportionately affected due to COVID-19, especially as urban are more likely to be classified as "containment zones"-thereby restricting most movement and income earning opportunities (NCAER, 2020). Yet, urban food systems in India have shown some resilience thus far.

There are several key lessons from the impacts of the lockdown. Macroeconomists in Indian focused heavily on the prospect of recessionary trends that will depress prices in general, including food prices in the early days of the lockdown. The Reserve Bank of India's Monetary Policy Committee report noted that even for those prices that have been high, such as for pulses "the shock to demand from COVID-19 may weaken (prices) going forward." Yet, our analysis suggests that in the near term, supply shocks more than counterbalance the collapse of demand leading to increase in food prices in many urban contexts. This suggests that notwithstanding longer-term trends, macroeconomists need factor into their policy proposals the possibility of short term and localized inflation. In general, such price rise justifies a sharp focus on emergency measures that expand food availability and feeding arrangements for a sustained period whenever processing and transportation bottlenecks surface.

Second, existing research on urban food systems in India note the complex mosaic of actors involved and the high degree of informality. Street vendors/retailers of food have always been 
marginalized, politically and economically (See Bhowmik, 2005, for example). ${ }^{40}$ Our field survey and anecdotal evidence suggest considerable resilience of informal vendors who have been adapting in response to severe constraints, despite their vulnerability. It is imperative that the government allows them freedom to operate and for law enforcers explicitly facilitate their functioning as the pandemic continues to unfold, but even beyond. At the time of writing, it is unclear how many have survived the lockdown period and will return to doing business. On the other hand, there have been many innovations in food supply chains at the producer end, especially in terms of collective efforts to get produce directly to customers. Perhaps this is an opportunity to consider collective retailing as well, bringing together informal street retailers, considering the critical role they play in maintaining the urban food system.

Third, it is important for the government to ensure that basic food processing industries, such as pulse mills, flour and sugar mills, crushing units and solvent extractors who produce edible oil are able to resume functioning with financial support where needed and to ensure the safety of workers in these industries. ${ }^{41}$ Many of these are small units that operate locally and would help ensure that supplies are available in the smaller cities and towns as well. It is possible that some of them, especially small-scale units, are financially vulnerable and may have difficulty continuing operations, especially with labor shortages. The revival of these units needs to be prioritized. The pandemic has generated calls for a decentralization of agrifood supply chains. These are likely already the case in India. Yet, India's experience during the lockdown suggest they too can be vulnerable to shocks.

As for government policies at times like this, many cities have tried to enforce price controls. ${ }^{42}$ It might be better focus on removing the supply chain bottlenecks and supporting supply chain actors rather than attempt to enforce a cap on prices, which puts disproportionate power in the hands of local law enforcement. ${ }^{43}$ This can include local governments and government-supported cooperatives to retail food at controlled prices. Enhancing supply is key to ensuring prices do not soar and would additionally minimize the impact of overzealous law enforcement. Even in the best of times, food prices in urban India put healthy diets largely out of reach for a majority of the urban poor (Raghunathan, et al., 2019). At this time, relief has been patchy at best. It is likely that even when

\footnotetext{
${ }^{40}$ There is a long history of struggle for the rights of these key players in the economy. A Supreme Court Judgement on September 9, 2013 and the Street Vendors (Protection of Livelihood and Regulation of Street Vending) Act, 2014 emerged from these struggles. National Association of Street Vendors in India (NASVI) and the National Hawker Federation are two prominent organisations in this area.

${ }^{41}$ Notifications on April 12 and April 21, 2020 permit these flour mills, etc. to operate in urban areas with appropriate measures for distancing. A recent estimate suggests that of 133 firms in the processed foods industry as per the Centre for Monitoring the Indian Economy (CMIE) Prowess database, 86 of these are deemed to be "liquidity vulnerable" firms, i.e., these have liquid assets cover for less than 90 days on minimum expenses (Sane and Sharma, 2020).

${ }^{42}$ On April 7, 2020, the Government of India issued a notification urging states to invoke the Essential Commodities Act, to tackle hoarding, black marketing, profiteering and speculative trading as interventions to prevent a rise in prices.

${ }^{43} \mathrm{https}: / /$ www.deccanherald.com/city/life-in-bengaluru/bbmp-fixes-prices-of-mutton-chicken-826765.html
} 
food prices recover the large number of workers who will continue to be out of work would need access to food and cash to help them tide over the crisis (Khera, 2020; Afridi, et al., 2020).

While short- and medium-term response is critical to stave off hunger in urban areas, the larger question is whether the innovations in food supply chains that have emerged in response to the crisis survive and how can these novel institutions be strengthened to aid the resilience of urban food systems. These questions will need scrutiny once the pandemic is over. 


\section{References}

Afridi, Farzana, Amrita Dhillon, Sanchari Roy (2020) How has Covid-19 crisis affected the urban poor? Findings from a phone survey, Ideas for India, April 23, 2020, https://www.ideasforindia.in/topics/povertyinequality/how-has-covid-19-crisis-affected-the-urban-poor-findings-from-a-phone-survey.html. Accessed April $23,2020$.

Bhowmik. Sharit, K. (2005). Street Vendors in Asia: A Review. Economic and Political Weekly, 40(22/23), 2256-2264. Retrieved April 21, 2020, from www.jstor.org/stable/4416705

Central Statistical Organization (2010) Manual on Consumer Price Index, Ministry of Statistics and Programme Implementation, Central Statistics Office, Government of India, New Delhi.

Hale, Thomas, Anna Petherick, Toby Phillips, Samuel Webster. "Variation in Government Responses to COVID-19" Version 4.0. Blavatnik School of Government Working Paper. April 7, 2020. Available: www.bsg.ox.ac.uk/covidtracker

Khera, Reetika (2020) What can be done immediately to help the vulnerable population? Ideas for India, March 25, 2020. https://www.ideasforindia.in/topics/poverty-inequality/covid-19-what-can-be-done-immediately-tohelp-vulnerable-population.html, Accessed March 25, 2020.

Mahajan, Kanika and Tomar, Shekhar, (2020) "Here Today, Gone Tomorrow: COVID-19 and Supply Chain Disruption". Available at https://papers.ssrn.com/sol3/papers.cfm?abstract id=3596720, Accessed May 27, 2020.

Narayanan, Sudha and Saha, Shree (2020) “One Step Behind: ”, Review of Agrarian Studies

Narayanan, Sudha (2008) “A Revolution in the Making: The Retail Revolution in India" Case Study \#6-2 in in Pinstrup-Andersen, Per and Cheng, Fuzhi (Eds.) Case Studies in Food Policy for Developing Countries: Institutions and International Trade Policies, Volume 2, First Edition, Cornell University Press, Ithaca, NY.

National Council for Applied Economic Research (2020) NCR Coronavirus Telephone Survey, National Data Innovation centre, NCAER, New Delhi. Accessed May 2, 2020.

National Sample Survey (2014) Household Consumption of Various Goods and Services in India, 2011-12, $68^{\text {th }}$ Round of the National Sample Survey, Ministry of Statistics and Programme Implementation, National Sample Survey Office, Government of India.

Raghunathan, Kalyani., Headey, Derek and Herforth, Anna (2019) Affordability of nutritious diets in rural India, International Food Policy Research Institute, Washington D.C. (Vol. 1912). Intl Food Policy Res Inst. 
Ramakumar, R. (2020) Farmers are at their wit's end, The Hindu, April 7, 2020.

Rawal, Vikas andd Kumar, Ankit (2020) Agricultural Supply Chains during the COVID-19 Lockdown: A Study of Market Arrivals of Seven Key Food Commodities in India, SSER Monograph 20/1, Society for Social and Economic Research. Accessed April 20, 2020.

Ray, Debraj, S.Subramanian and Vandewalle, Lore (2020), “India's Lockdown”, CEPR Policy Insight No. 102. https://cepr.org/active/publications/policy insights/viewpi.php?pino=102, Accessed May 1, 2020.

Reardon, Thomas and Minten, Bart (2011), "Surprised by supermarkets: diffusion of modern food retail in India", Journal of Agribusiness in Developing and Emerging Economies, Vol. 1 No. 2, pp. 134-

161. https://doi.org/10.1108/20440831111167155

Reardon, Thomas, Mishra, Ashok, Nuthalapati, Chandra S R, Bellemare Marc F, Zilberman, David, (2020) COVID-19's Disruption of India's Transformed Food Supply Chains, Economic and Political Weekly, 55(18): $18-22$

Reserve Bank of India (2020) Monetary Policy Report - April 2020https://www.rbi.org.in/Scripts/PublicationsView.aspx?id=19439\#21. Accessed April 25, 2020.

Reserve Bank of India (2020) Seventh Bi-monthly Monetary Policy Statement, 2019-20 Resolution of the Monetary Policy Committee (MPC) Reserve Bank of India, March 27, 2020, Press release. Available here https://rbidocs.rbi.org.in/rdocs/PressRelease/PDFs/PR2129F5E23A447E0F4A00955429716C53F5A2.PDF. Accessed on April 20, 2020

Sane, Renuka and Sharma, Anjali (2020) Holding their breath: Indian firms in an interruption of revenue, The LEAP Blog, April 3, 2020. https://blog.theleapjournal.org/2020/04/holding-their-breath-indian-firms-in.html. Accessed April 20,2020.

Seth, Aaditeswar and Vishwanathan, Vani (2020) “'What Covid-19 Means To Us' Voices from the Indian Hinterland", The India Forum, May 1, 2020. Accessed May 1, 2020.

Suneja, Kritika , Noronha, Gaurav (2020) March CPI inflation figures may have caveats as data suffers due to Covid lockdown Economic Times, March 30, 2020. Accessed March 31, 2020.

SWAN (2020) 21 Days and Counting: COVID-19 Lockdown, Migrant Workers, and the Inadequacy of Welfare Measures in India, Stranded Workers Action Network (SWAN), Azim Premji University, Bengaluru, India.

Thaker, Naini (2020) Lockdown: How agritech ventures are trying to fix the food supply chain, Forbes India, April 22, 2020. https://www.forbesindia.com/article/coronavirus/lockdown-how-agritech-ventures-are-trying-tofix-the-food-supply-chain/58955/1. Accessed April 27, 2020. 
Vrutti \& Arya (2020) Going Viral: Opportunities for leadership by FPOs in Covid-19 response, A Study by Vrutti and Arya. 